\title{
PENGARUH PENAMBAHAN EKSTRAK DAUN BELUNTAS DAN AZOLLA TERHADAP INCOME OVER FEED COST (IOFC) DAN NILAI EKONOMIS PAKAN ITIK PEDAGING
}

\author{
Doroteus Popot Simi, Dyah Lestari Yulianti, Aju Tjatur Nugroho Krisnaningsih \\ Fakultas Peternakan \\ Universitas Kanjuruhan Malang \\ Email: dyah_ly@gmail.com
}

\begin{abstract}
Abstrak
Tujuan dari penelitian ini adalah untuk mengetahui pengaruh penggunaan ekstrak daunbeluntas dan Azolla terhadap inccome over feed cost dan nilai ekonomis pakanitik pedaging. Materi yang digunakan dalam penelitian ini adalah 48 ekor itik pedaging dan bahan dengan komposisi sesuai dengan standar kebutuhan itik pedaging serta beluntas dan. Metode yang digunakan dalam penelitian ini adalah metode percobaan Lapang dengan menggunakan Rancangan Acak Lengkap (RAL) yaitu 4 perlakuan dan setiap perlakuan diulangi sebanyak 4 kali. Masing-masing percobaan diisi dengan 3 ekor itik. Perlakuan dalam penelitian ini adalah P0: (complete feed 100\%), P1: complete feed 50\% + ((azolla 85\%) + (ekstrak bluntas 15\%) 50\%); P2: complete feed $50 \%+(($ azolla $90 \%)+($ ekstrak bluntas $10 \%) 50 \%)$, P3: complete feed $50 \%+(($ azolla $95 \%)+($ ekstrak bluntas $5 \%$ )50\%). Variabel yang diamati dalam penelitian ini adalah inccome over feed cost dan nilai ekonomis pakan itik pedaging, dan di analisis dengan menggunakan analisis ragam dengan rancangan Acak Lengkap (RAL). Apa bila antara perlakuan ada perbedaan, dilanjutkan dengan Uji BNT.Hasil penelitian menunjukan bahwa IOFC tertinggi pada perlakuan P0 dan terendah pada perlakuan P3. Dengan nilai P0 sebesar Rp 6.262 dan nilai P3 sebesar Rp 605. Sedangkan Nilai ekonomis yang tertinggi terdapat pada kelompok P3 dan terendah pada P1 dengan nilai P3 Rp 27.940 dan nilai P1 sebesar Rp 26.312. Berdasarkan hasil penelitian disimpulkan bahwa pengguanaan ekstrak daun bluntas dan azolla sebagai pakan fermentasi sampai level 95\% tidak memberikan pengaruh terhadap inccome over feed cost (IOFC), danNilai ekonomis pakan.
\end{abstract}

Kata kunci: ekstrak, daun beluntas, azolla, IOFC, nilai ekonomis pakan, itik pedaging.

\section{THE EFFECT OF USING BLUNTAS EXTRAXT AND AZOLLA ON INCOME OVER FEED COST ( IOFC) OF DUCK REARLING}

\begin{abstract}
The purpose of this research is to know the effect of using bluntas extract and Azolla as addition feed for inccome over feed cost and the economic value of ducks feed. The subject of this research were 48 ducks, complete feed, bluntas and azolla. Field exprerimental method was a method that was used in this research by using (completely randomized design) wherareas 4 treatments were applied. Each of treatment was repeated 4 times. The treatment of this researc were P0 : (complete feed 100\%), P1: complete feed 50\% +((azolla 85\%)+(bluntas exstract 15\%) $50 \%)$, P2: complete feed 50\%, +((azolla 90\%)+(bluntas exstract 10\%) 50\%), P3: complete feed $50 \%,+(($ azolla $95 \%)+($ bluntas exstract $5 \%) 50 \%)$. Variable of this study was income over feed cost and the economic value of ducks feed. The result of this study showed that the higher income over feed founded on treatment of P0 group with Rp. 2626 mean while the lowest on P2 group with Rp. 605. Wide result shows that the treatment give real effect $(\mathrm{P}<0,05)$ to IOFC of ducks. There was significant affect of IOFC and the economic value of boiler ducks feed. It was concluded that the combination of the level of protein interaction and Azolla and Bluntas. Obtained an IOFC of Rp 6.626, with production economic value of ducks feed of Rp 27. 940, at the age of 5 weeks Hbri ducks (P3)
\end{abstract}

Keywords: Bluntas, Azolla, Income Over Feed Cost and ducks 


\section{Jurnal Sains Peternakan}

Vol 6, No 1, Juni 2018, pp: 42-46

ISSN 2579-4450

\section{PENDAHULUAN}

Usaha bidang pemeliharaan ternak unggas khususnya itik kini semakin berkembang dengan baik. Itik merupakan jenis unggas yang memiliki potensi dwiguna yaitu sebagai penghasil telur dan daging. Ternak itik merupakan salah satu alternatif yang dapat di gunakan untuk mendukung kebutuhan masyarakat akan pangan bergizi. Selain itu, itik memiliki kemampuan lebih tahan terhadap penyakit, dapat di pelihara dengan air dan tanpa air serta pertumbuhannya lebih cepat dari ayam buras (Srigandono,1998). Pengembangan usaha peternakan itik pedaging di Indonesia saat ini masih mengalami berbagai kendala. Salah satu kendala dalam pengembangan usaha peternakan khususnya ternak itik yaitu penyediaan pakan yang berkualitas baik. Kendala dalam penyediaan pakan meliputi ketersediaan bahan baku pakan yang bernilai nutrisi, harga mahal terutama sumber protein dalam pakan yang masih impor seperti tepung ikan dan bungkil kedelai. Pada usaha peternakan biaya pakan mencapai $60 \%-70 \%$ dari total biaya produksi. Untuk menekan biaya pakan tersebut perlu dilakukan usaha untuk mencari sumber bahan baku yang lebih murah, mudah didapat, bergizi baik, tetapi tidak bersaing dengan kebutuhan manusia. Untuk itu perlu digali potensi bahan pakan yang banyak tersedia dalam negeri.

Beluntas memiliki kesamaan dengan Azolla memiliki kandungan protein tinggi dan beluntas juga memiliki kandungan nutrisi lengkap dan baik sebagai pakan, yaitu protein kasar sebesar 19,2\%, Serat kasar 11,49\%, dan lemak kasar 15,80\%.Penggunaan Azolla microphylla dan bluntas serta level protein pakan yang berbeda dalam pakan di harapkan mampu meningkatkan bobot, persentase karkas dan bagian-bagian karkas itik pedaging, karena dengan penambahan Azolla microphylla dan ekstrak beluntas dalam pakan diharapkan mampu memenuhi kebutuhan protein pakan pada itik. Azolla yang digunakan sebagai suplementasi bahan pakan kaya akan nutrisi dan selain tinggi protein yaitu sekitar 25-35\%, juga kaya asam amino esensial, vitamin (vitamin A, vitamin B12 dan beta karoten) juga mineral ( $\mathrm{Ca}, \mathrm{P}, \mathrm{Fe}$, dan $\mathrm{Mg})$.

\section{MATERI DAN METODE}

Materi Penelitian yang digunakan adalah itik pedanging hybidra (persilangan antara itik mojosari dengan itik alabio) sebanyak 48 ekor, yang berumur 7 hari, di beri perlakuan dan di pelihara dengan sistem litter selama 40 hari, ekstrak daun beluntas, daun azolla dan pakan complete feed.

Metode yang di gunakan dalam penelitian ini adalah Penelitian Lapangan dengan menggunakan Rancangan Acak Lengkap (RAL) yang terdiri dari 4 perlakuan dan 


\section{Jurnal Sains Peternakan}

Vol 6, No 1, Juni 2018, pp: 42-46

ISSN 2579-4450

masing-masing perlakuan terdiri dari 4 ulangan, dan masing- masing perlakuan terdiri dari 3 ekor itik apabila menunjukan pengaruh yang nyata akan di lanjut dengan uji BNT.

Perlakuan penelitian yang dilaksanakan adalah:

P0: (100\% complete feed)

P1: (complete feed 50\% + (azolla 85\% + ekstrak beluntas 15\%) 50\%)

P2: (complete feed 50\% + azolla 90\% + ekstrak beluntas 10\%) 50\%)

P3: (complete feed 50\% + azolla 95\% + ekstrak beluntas 5\%)50\%)

Variabel yang di amati dalam penelitian ini inccome over feed costdan nilai ekonomis pakanitik pedaging. Data yang diperoleh (income over feed cost) dan nilai ekonomis pakan di analisis dengan menggunakan analisis ragam dengan rancangan Acak Lengkap (RAL).Apa bila antara perlakuan ada perbedaan, dilanjutkan

\section{HASIL DAN PEMBAHASAN}

Setelah dilakukan penelitian selama 40 hari, diperoleh hasil rata-rata konsumsi pakan, BB saat panen dan Konversi pakan di sajikan pada Tabel 1. rata-rata IOFC dan nilai ekonomis pakan untuk masing- masing perlakuan di sajikan pada tabel 1.

Tabel 1. Rata -rata konsumsi pakan, BB saat panen dan konversi pakan

\begin{tabular}{cccr}
\hline Perlakuan & $\begin{array}{l}\text { Konsumsi Pakan } \\
\text { (g/ekor) }\end{array}$ & $\begin{array}{c}\text { BB Saat Panen } \\
(\mathrm{g} / \text { ekor })\end{array}$ & Konversi Pakan \\
\hline P0 & $2.433,27^{\mathrm{a}}$ & 1133,33 & 2,14 \\
P1 & $3.514,95^{\mathrm{b}}$ & 1141,67 & 3,08 \\
P2 & $3.464,97^{\mathrm{b}}$ & 1063,32 & 3,26 \\
P3 & $3.682,47^{\mathrm{b}}$ & 1094,99 & 3,37 \\
\hline
\end{tabular}

Sumber : data penelitian diolah.

\section{Pengaruh Ekstrak Beluntas dan Azolla Terhadap Konsumsi Pakan}

Berdasarkan tabel 1 diatas terlihat bahwa konsumsi pakan pada masing-masing perlakuan dari P0 hingga P3 mengalami peningkatan. Sedangkan untuk bobot badan dari masing-masing perlakuan, terlihat bahwa pada perlakuan P2 dan P3 bobot badan itik lebih rendah jika di bandingkan dengan perlakuan P0 dan P1. Rendahnnya bobot badan itik pada pada perlakuan P2 dan P3, di karenakan pada perlakuan P2 dan P3 level pemberian ekstrak beluntas dan azolla lebih banyak yang mengakibatkan banyaknya serat kasar yang terkandung dalam pakan itik sehingga pakan yang di konsumsi tidak banyak di serap oleh tubuh itik sehingga berdampak terjadinya penurunan bobot badan itik.

Tabel 2. Rata-rata IOFC dan nilai ekonomis pakan itik pedaging

\begin{tabular}{lrr}
\hline Perlakuan & IOFC (Rp/ ekor) & Nilai Ekonomis Pakan $(\mathrm{Rp} / \mathrm{kg}$ \\
\hline P0 & $6.262 \pm 1949,9$ & $17.120 \pm 2225,4$ \\
P1 & $3.581 \pm 1568,3$ & $18.865 \pm 2207,4$ \\
\hline
\end{tabular}


Jurnal Sains Peternakan

Vol 6, No 1, Juni 2018, pp: 42-46

ISSN 2579-4450

\begin{tabular}{lrr}
\hline P2 & $1.561 \pm 968,9$ & $20.375 \pm 1224,9$ \\
P3 & $605 \pm 140,6$ & $21.483 \pm 1943,3$ \\
\hline
\end{tabular}

Sumber : data penetian diolah

Pengaruh Ekstrak Beluntas dan Azolla Terhadap Inccome Over Feed Cost (IOFC) Itik Pedaging

Berdasarkan hasil analisis Pada tabel terlihat bahwa inccome over feed cost selama penelitian yang tertinggi terdapat pada perlakuan $\mathrm{P} 0$ ( $\mathrm{Rp}$ 6.262) kemudian berturut-turut pada perlakuan P1 (Rp 3.581), P2 (Rp 1.561),dan P3 (Rp 605). Analisis ragam menunjukkan bahwa perlakuan tidak berpengaruh nyata $(\mathrm{P}>0,05)$ terhadap Inccome over feed costitik pedaging.

Tinggi rendahnyalnccome over feed cost (IOFC) itik pedaging sangat berpengaruh oleh biaya pakan dan penerimaan selama penelitian. Rendahnya IOFC pada perlakuan P1, P2, dan P3 hal ini disebabkan oleh akibat adanya kandungankandungan air dan serat kasar yang tinggi yang terdapat pada tumbuhan azolla mengakibatkan kebutuhan gizi pada itik pedaging berkurang. Berkurangnya kebutuhan gizi pada itik pedaging berdampak terhadap penurunan bobot badan dan angka penerimaan.

\section{Pengaruh Ekstrak Beluntas dan Azolla Terhadap Nilai Ekonomis Pakan Itik Pedaging}

Nilai ekonomis pakan tertinggi pada perlakuan P3 (Rp 27.940) dan terendah pada pelakuan P0 (Rp 20.863) kemudian pada P1 (Rp 23.862) dan P2 (Rp 26.312). Berdasarkan hasil analisisinteraksi level penambahan ekstrak daun beluntas dan daun azolla terhadap nilai ekonomis pakan itik pedaging memberikan tidak berpengaruh nyata $(\mathrm{P}>0,05)$ terhadap nilai ekonomis pakan itik pedaging. Tingginya nilai ekonomis pakan itik pedaging dalam penelitian ini di sebabkan oleh banyaknya pakan yang dihabiskan lebih besar dari biaya pakan.

Secara ekonomis penggunaan ekstrak daun Bluntas dan Azolla sebagai pakan tambahan tidak efisien. Dikarenakan penggunaan ekstrak bluntas dan daun azolla memberikan pengaruh terhadap biaya pakan yang tinggi serta penurunan bobot badan itik yang berdampak terhadap rendahnya IOFC.

\section{KESIMPULAN}




\section{Jurnal Sains Peternakan}

Vol 6, No 1, Juni 2018, pp: 42-46

ISSN 2579-4450

Berdasarkan hasil penelitian disimpulkan bahwa pengguanaan ekstrak daun beluntas dan azola sebagai pakan fermentasi sampai level 95\% tidak memberikan pengaruh terhadap inccome over feed cost (IOFC), dan terhadap nilai ekonomis pakan

\section{UCAPAN TERIMA KASIH}

Ucapan terima kasih disampaikan kepada semua pihak terutama Laboratorium Terpadu Fakultas Peternakan Universitas Kanjuruhan Malang yang telah banyak membantu sejak persiapan hingga terselenggaranya penelitian ini dengan baik.

\section{DAFTAR PUSTAKA}

AdiSaputra. 2010. Kebutuhan Gizi Unggas. Majalah Pertanian dan Peternakan, 17 (09).

Agus.2010. Kebutuhan Gizi Ternak Unggas. Jakarta: Agro Media Pustaka

Dewinter dan Amororso, 2003 Chemikal compsition and the feeding value of azolla (Azollapinnata) meal for egg-type chicks .Int .J .Poult.Sci .5(2): 137-141

Ditjenak. 2004. Buku Statistik Peternakan. Direktorat Jendral Bina Produksi Peternakan. Depertemen pertanian RI Jakarta.

Djojosuwito. 2001. Azolla: Biology and Agronomic Significance. Bot. Rev. 35: 17.

Kuswadi. 2000. Bisakah azolla untuk pakan ternak. Majalah Pertanian dan Peternakan, $15(03)$.

Latifah. 2007. Itik Petelur. Jakarta: Penebar Swadaya. 